\title{
Priming and drying on the physiological quality of eggplant seeds
}

\author{
Delineide P Gomes; Alexandre F da Silva; Denise Cunha FS Dias; Eveline M Alvarenga; Laércio J da \\ Silva; Luis Eduardo Panozzo \\ UFV-Dep ${ }^{\text {to }}$ Fitotecnia, 36570-000 Viçosa-MG; agroneide@hotmail.com; afsilva9@hotmail.com; dcunhadias@gmail.com; eveline@ufv. \\ br; laerciojunio@yahoo.com.br; lpanozzo@gmail.com
}

\begin{abstract}
We evaluated the effect of the priming with polyethyleneglicol (PEG) 6000 followed or not of drying on two lots of eggplant seeds with medium and low vigor respectively. The seeds were submitted to the treatments of priming with PEG 6000 in the osmotic potentials of $-0.6,-0.9$ and $-1.2 \mathrm{MPa}$ during 48 or 96 hours of priming with and without subsequent drying. For the soaking of seeds in osmotic solutions, these were placed over three sheets of paper boxes such germitest gerbox conditioning moistened with each solution in a $3: 1$ ratio. The control group was represented by unprimed seeds. The priming for both lots provided higher values in relation to the vigor through the first counting of germination, seedlings and primary root length, germination and emergence rates, emergence and dry weight of seedlings when compared to the non-primed seeds. These results were not verified for germination; significant differences practically were not observed in relation to the controls. Improvements in relation to the vigour were not higher on lot 2 than those obtained on lot 1 . The priming with PEG 6000 with subsequent drying increased the vigor of eggplant seeds of the cultivar Morro Grande in relation to those non-primed, however, without differences in the germination.
\end{abstract}

Keywords: Solanum gilo, priming, vigor, germination.

\section{RESUMO}

Condicionamento osmótico e secagem na qualidade fisiológica de sementes de jiló

Este trabalho teve como objetivo avaliar o efeito do osmocondicionamento, seguido ou não de secagem, em dois lotes de sementes de jiló com baixo e médio vigor. As sementes foram submetidas aos tratamentos de condicionamento osmótico com polietileno glicol (PEG) 6000 nos potenciais osmóticos de -0,6, -0,9 e -1,2 MPa, por períodos de 48 e 96 horas, com e sem secagem após os tratamentos. Para a embebição das sementes nas soluções osmóticas, estas foram colocadas sobre três folhas de papel germitest em caixas tipo gerbox umedecidas com cada solução condicionadora na proporção de $3: 1$. A testemunha consistiu de sementes não condicionadas. O osmocondicionamento, para ambos os lotes, proporcionou resultados superiores quanto ao vigor, pelos testes de primeira contagem, comprimento de hipocótilo e de radícula, IVG, IVE, emergência e massa seca de plântulas, quando comparados às testemunhas não condicionadas. O mesmo não foi verificado para a germinação, pois praticamente não foram observadas diferenças em relação à testemunha dos lotes. Para o lote 2, as melhorias quanto ao vigor não foram maiores do que aquelas obtidas no lote 1 . O condicionamento osmótico das sementes de jiló com PEG 6000 e com secagem posterior proporciona aumento no vigor das sementes dos lotes de jiló da cultivar Morro Grande, em relação àquelas não condicionadas, entretanto, sem diferenças na germinação.

Palavras chave: Solanum gilo, osmocondicionamento, vigor, germinação.

(Recebido para publicação em 5 de maio de 2011; aceito em 31 de julho de 2012) (Received on May 5, 2011; accepted on July 31, 2012)

$\mathrm{T}^{\mathrm{s}}$ he eggplant (Solanum gilo) belongs to the Solanaceae family and probably originated in Africa was brought to Brazil by slaves. According to Odetola et al. (2004), this plant contains flavonoids, alkaloids and steroids and its roots have antioxidant properties that can lower the cholesterol level. It is a vegetable cultivated mainly in the south-eastern region of Brazil and surprisingly, has been widely accepted on the market and is currently much appreciated in bars and restaurants.

It is propagated by seeds so that using seeds with high germination and vigor ensures producers a greater likelihood of success in establishing the crop.

In vegetable production, techniques such as osmotic conditioning are desirable because they increase germination and emergence percentages and speed of seedlings in the field and improve seed performance under stress conditions. According to Lima \& Marcos Filho (2009) seedling production on trays requires highly efficient seed performance to obtain vigorous uniform seedlings in a shorter period of time.

In this technique, seeds are submitted to controlled hydration in an osmotic solution with time and temperature appropriate for the species that allows the reactivation of pre-germination metabolic events without, however, allowing the protusion of primary root (Heydecker et al., 1975). Promising results obtained using priming have been reported for several vegetable species such as lettuce (Fessel et al., 2001) carrot (Balbinot \& Lopes, 2006; Pereira et al., 2009), asparagus (Bittencourt et 
al., 2004a, 2004b; 2005), cauliflower (Marcos Filho \& Kikuti, 2008), onion (Nunes et al., 2000; Caseiro et al., 2004), beetroot (Dias et al., 2009), cucumber (Lima \& Marcos Filho, 2009), tomato (Rosseto et al., 2002), sweet pepper (Roveri-José et al., 2000; Pereira et al., 2005), eggplant (Fanan \& Novembre, 2007) and okra (Dias et al., 1999). However, to date there has been little research regarding eggplant seeds.

Some factors should be considered when defining the most suitable conditions for the priming of seeds of a determined species including the osmotic agent, osmotic potential of the solution, imbibition temperature and period, solution aeration and seed drying after treatment. According to Lopes \& Souza (2008), in addition to the species, the cultivar and within the same cultivar, the vigor level of the seed lot is also an important factor. In asparagus seeds, beneficial effects of priming were more expressive on the germination speed and vigor of low physiological quality lots; however, under water and heat stress conditions, this effect was observed both for high and low quality lots (Bittencourt et al., 2004a; 2005).

Currently polyethyleneglicol (PEG) is the solute most used for seed priming because it is a high weight molecular polymer, inert and not toxic to the seeds (Heydecker et al., 1975). In general, the results with vegetable priming have indicated osmotic potentials ranging from -0.5 to $-2.0 \mathrm{MPa}$ and the temperature used for the treatment has been that recommended for seed germination (Nascimento, 1998).

Regarding research with some Solanaceae, priming was shown to be effective in improving seed quality. For example, with sweet pepper seeds, Roveri-José et al. (2000) reported that the combination of $-1.1 \mathrm{MPa}$ PEG 6000 for eight days and $25^{\circ} \mathrm{C}$ increased the emergence speed. Rosseto et. al. (2002) verified that tomato seeds primed with PEG 6000 at 0.0 and -1.0 MPa for seven days at $20^{\circ} \mathrm{C}$, evaluated immediately after the treatments and after up to 60 days storage, presented high germination and vigor. Fanan \& Novembre (2007) observed that there was a possibility of eggplant seeds priming using -0.5 MPa PEG 6000 followed by seed drying.

There is a controversial aspect related to the effect of seed drying after priming on treatment results. In some studies, reversal of the beneficial effects of the seed priming have been observed after drying (Argerich et al., 1989), but others have shown favorable results (Balbinot \& Lopes, 2006; Kikuti, 2006; Fanan \& Novembre, 2007). For Heydecker et al. (1975), primed seeds can be submitted to drying until they reach their original water content and can be stored for several weeks, with little loss of the treatment effect. Balbinot \& Lopes (2006) also stated that drying seeds after priming was desirable because it facilitated their handling and storage, preventing exposure of the seeds to risk of mechanical damage from sowing equipment. These authors verified that carrot seed priming followed by drying did not affect germination and contributed to increasing the seed vigor. The beneficial effects of priming were maintained in cauliflower seeds after a quick drying process (Kikuti, 2006).

Thus the objective of the present study was to assess the effects of priming and drying on two seed lots of eggplant with medium and low vigor.

\section{MATERIAL AND METHODS}

The experiment was carried out in the laboratory of the Universidade Federal de Viçosa from April to June 2009.

Two lots of eggplant seeds, cultivar Morro Grande, were used which were classified as medium vigor (lot 1) and low vigor (lot 2) based on initial seed quality tests, such as the first count and controlled deterioration. The initial seed moisture content was 8.4 and $7.8 \%$ for lot 1 and lot 2, respectively.

After characterizing the initial quality of the lots, the seeds were submitted to priming treatments in solutions of polyethyleneglicol 6000 (PEG 6000) at the osmotic potentials of $-0.6,-0.9$ and $-1.2 \mathrm{MPa}$, that corresponded to $235 \mathrm{~g}$ $\mathrm{L}^{-1}, 292 \mathrm{~g} \mathrm{~L}^{-1}$ and $340 \mathrm{~g} \mathrm{~L}^{-1}$ PEG 6000, respectively (Villela et al., 1991). For imbibition in the osmotic solution, the seeds were placed on three sheets of germitest paper moistened with each osmotic solution at the proportion of $3: 1$ (solution:paper weight) in germination box. The solution volume was adjusted to ensure that the seeds came into contact with the product but their respiration was not restricted. The boxes containing the seeds were closed and kept in a germinator at $30^{\circ} \mathrm{C}$ for 48 and 96 hours. After these periods, the seeds were washed in running water to eliminate solution residues and part of them were placed on paper towel sheets to dry under laboratory conditions $\left(20^{\circ} \mathrm{C}\right.$ and $40 \%$ relative humidity) until they reached water content close to the initial content. The seed water content, immediately after priming and drying, was determined by the oven method at $105 \pm 3{ }^{\circ} \mathrm{C}$ (Brasil, 1992). Primed seeds, dried or not, were submitted to the following tests to assess their physiological potential.

Germination - Four 50-seed subsamples were used, sown on paper towel moistened with distilled water at 2.5:1 (water:paper weight) in gerboxes and placed in a germinator at $30^{\circ} \mathrm{C}$. Seedlings were counted on the $6^{\text {th }}$ and $14^{\text {th }}$ days after sowing and the percentage of normal seedlings was calculated (Brazil 1992).

First count of germination - carried out together with the germination test, the percentage of normal plants was recorded on the sixth day after sowing.

Hypocotyl and primary root length - the same method was adopted as described for the germination test, using four 20 -seed replications. The assessment was made 14 days after sowing by measuring the hipocotyle and primary root length of the normal seedlings and obtaining the average value, expressed in centimeters per seedling (Nakagawa, 1999).

Germination speed index - carried out at the same time as the germination test, with daily assessments until the $14^{\text {th }}$ day after sowing. The GSI was calculated according to Nakagawa (1999).

Emergence speed percentage and index - four 50-seed sub-samples of each treatment were sown on 200-well extruded polystyrene trays filled with 
Table 1. Germination, first count germination, hypocotyl length, radicle length, germination speed index (GSI), emergence speed index (ESI), emergence and seedling dry mass of seeds from two lots of eggplant (1 and 2) with medium and low vigor, respectively due to the presence or absence of priming and drying (germinação, primeira contagem da germinação, comprimento de hipocótilo, comprimento de radícula, índice de velocidade de germinação (GSI), índice de velocidade de emergência (ESI), emergência e massa seca de plântulas de sementes de dois lotes de jiló (1 e 2) com médio e baixo vigor, respectivamente em função da presença ou não de condicionamento osmótico e da secagem). Viçosa, UFV, 2009.

\begin{tabular}{|c|c|c|c|c|c|c|c|c|}
\hline \multirow[t]{2}{*}{ Treatment } & \multicolumn{2}{|c|}{$\begin{array}{c}\text { Germination } \\
(\%)\end{array}$} & \multicolumn{2}{|c|}{$\begin{array}{c}\text { First counting } \\
(\%)\end{array}$} & \multicolumn{2}{|c|}{$\begin{array}{l}\text { Hypocotyl length } \\
\text { (cm) }\end{array}$} & \multicolumn{2}{|c|}{$\begin{array}{l}\text { Radicle length } \\
(\mathrm{cm})\end{array}$} \\
\hline & Lot 1 & Lot 2 & Lot 1 & Lot 2 & Lot 1 & Lot 2 & Lot 1 & Lot 2 \\
\hline \multirow[t]{2}{*}{ Non-primed seeds } & 88.0 & 51.0 & 73.0 & 15.0 & 1.2 & 0.7 & 0.6 & 0.3 \\
\hline & \multicolumn{8}{|c|}{ With drying } \\
\hline$-0,6$ MPfor $48 \mathrm{~h}$ & 77.0 & 43.0 & 64.0 & 19.0 & 1.5 & 0.7 & 0.9 & 0.4 \\
\hline -0,6MPfor96h & 92.0 & 56.0 & 64.0 & $30.0 *$ & 1.4 & 0.9 & 0.7 & 0.3 \\
\hline$-0,9$ MPfor $48 \mathrm{~h}$ & 93.0 & 47.0 & 79.0 & $42.0^{*}$ & 1.3 & 0.9 & 1.1 & 0.4 \\
\hline -0,9MPfor96h & 90.0 & 46.0 & 85.0 & 20.0 & $2.4^{*}$ & 0.8 & $1.4^{*}$ & 0.4 \\
\hline -1,2MPfor $48 \mathrm{~h}$ & 93.0 & 53.0 & 76.0 & $39.0 *$ & 1.8 & 1.7 & 1.0 & 0.3 \\
\hline \multirow[t]{2}{*}{-1,2MPfor96h } & 88.0 & 43.0 & 81.0 & 27.0 & $2.5^{*}$ & 1.1 & $1.8 *$ & 0.4 \\
\hline & \multicolumn{8}{|c|}{ Without drying } \\
\hline$-0,6$ MPfor $48 \mathrm{~h}$ & 79.0 & 51.0 & 57.0 & 20.0 & 1.1 & 1.4 & 0.6 & 0.1 \\
\hline$-0,6 \mathrm{MPfor} 96 \mathrm{~h}$ & 90.0 & 49.0 & 84.0 & $44.0^{*}$ & 1.8 & 1.2 & 1.0 & 0.4 \\
\hline$-0,9 \mathrm{MPfor} 48 \mathrm{~h}$ & 91.0 & 47.0 & 82.0 & $35.0 *$ & $2.3 *$ & 1.1 & $1.4^{*}$ & 0.4 \\
\hline -0,9MPfor96h & 93.0 & 50.0 & $92.0 *$ & $34.0 *$ & 1.9 & 0.8 & $1.7^{*}$ & 0.4 \\
\hline -1,2MPfor $48 \mathrm{~h}$ & 94.0 & 55.0 & 83.0 & $39.0 *$ & 1.9 & 1.2 & 1.0 & 0.5 \\
\hline -1,2MPfor96h & 92.0 & 44.0 & $88.0 *$ & 15.0 & $2.4^{*}$ & 1.2 & $1.3 *$ & 0.5 \\
\hline CV $(\%)$ & 6.8 & 8.1 & 8.2 & 13.7 & 20.3 & 28.3 & 24.5 & 29.5 \\
\hline
\end{tabular}

\begin{tabular}{|c|c|c|c|c|c|c|c|c|}
\hline \multirow[t]{2}{*}{ Treatment } & \multicolumn{2}{|c|}{$\begin{array}{c}\text { GSI } \\
\text { (plantlet/day) }\end{array}$} & \multicolumn{2}{|c|}{$\begin{array}{c}\text { ESI } \\
\text { (plantlet/day) }\end{array}$} & \multicolumn{2}{|c|}{$\begin{array}{c}\text { Emergence } \\
(\%)\end{array}$} & \multicolumn{2}{|c|}{$\begin{array}{c}\text { Dry mass } \\
\text { (mg/plantlet) }\end{array}$} \\
\hline & Lot 1 & Lot 2 & Lot 1 & Lot 2 & Lot 1 & Lot 2 & Lot 1 & Lot 2 \\
\hline \multirow[t]{2}{*}{ Non-primed seeds } & 5.8 & 2.2 & 4.7 & 2.1 & 87.0 & 32.0 & 4.0 & 2.5 \\
\hline & \multicolumn{8}{|c|}{ With drying } \\
\hline$-0,6$ MPfor $48 \mathrm{~h}$ & $9.7^{*}$ & 2.8 & $5.9^{*}$ & 2.8 & $96.0 *$ & $63.0 *$ & 4.5 & 3.0 \\
\hline$-0,6 \mathrm{MPfor} 96 \mathrm{~h}$ & $8.7 *$ & $7.6^{*}$ & $6.2 *$ & $4.1^{*}$ & 94.0 & $67.0 *$ & 3.0 & 3.3 \\
\hline$-0,9$ MPfor $48 \mathrm{~h}$ & 7.4 & $4.4^{*}$ & $6.3^{*}$ & $3.4^{*}$ & 92.0 & $69.0 *$ & 7.7 & 3.0 \\
\hline$-0,9$ MPfor $96 \mathrm{~h}$ & $21.0^{*}$ & $12.0 *$ & $8.1^{*}$ & $4.6^{*}$ & 93.0 & $72.0 *$ & 5.2 & 3.5 \\
\hline$-1,2 \mathrm{MPfor} 48 \mathrm{~h}$ & 7.7 & $4.2 *$ & $6.1^{*}$ & 2.8 & $99.0^{*}$ & $70.0^{*}$ & 6.7 & 3.5 \\
\hline \multirow[t]{2}{*}{-1,2MPfor96h } & $20.0^{*}$ & 3.8 & $6.4^{*}$ & $4.1^{*}$ & 92.0 & $63.0 *$ & 6.5 & 4.3 \\
\hline & \multicolumn{8}{|c|}{ Without drying } \\
\hline$-0,6$ MPfor $48 \mathrm{~h}$ & 6.3 & 2.7 & $5.7 *$ & 2.5 & $97.0 *$ & $56.0 *$ & 3.3 & 1.8 \\
\hline$-0,6 \mathrm{MPfor} 96 \mathrm{~h}$ & $10.0^{*}$ & 2.8 & $5.7 *$ & 2.9 & 92.0 & $61.0^{*}$ & $7.5^{*}$ & 3.8 \\
\hline$-0,9$ MPfor $48 \mathrm{~h}$ & $8.8^{*}$ & 4.0 & $6.2 *$ & $3.3 *$ & $95.0 *$ & $65.0^{*}$ & 6.5 & 3.3 \\
\hline$-0,9$ MPfor96h & $20.0 *$ & $8.2^{*}$ & $7.7^{*}$ & $4.2 *$ & $98.0 *$ & $66.0^{*}$ & 6.5 & $4.3^{*}$ \\
\hline -1,2MPfor $48 \mathrm{~h}$ & $10.0^{*}$ & 4.0 & $5.7 *$ & 2.6 & 93.0 & $69.0 *$ & $7.3^{*}$ & $5.0^{*}$ \\
\hline -1,2MPfor96h & $14.0^{*}$ & $4.9^{*}$ & $5.7^{*}$ & 2.9 & $99.0^{*}$ & $68.0^{*}$ & $7.3^{*}$ & $5.0^{*}$ \\
\hline CV (\%) & 10.2 & 18.5 & 4.8 & 14.1 & 3.8 & 9.2 & 23.4 & 33.1 \\
\hline
\end{tabular}

In the column, means followed by * differ statistically by Dunnett's test at $5 \%$ probability (na coluna, médias seguidas de * diferem estatisticamente pelo teste de Dunnett ao nível de 5\% de probabilidade). 
commercial substrate and one seed was $0.5 \mathrm{~cm}$ deep placed per well. The number of normal plants was counted daily until the $14^{\text {th }}$ day after sowing in the greenhouse. The percentage was calculated of normal plants at 14 days after sowing and the GSI was calculated according to Maguire (1962).

Seedling dry matter - carried out together with the seedling test, the normal seedlings were dried in an oven at $70^{\circ} \mathrm{C}$ for 24 hours and later weighed, according to Nakagawa (1999). The mean dry matter obtained per seedling was expressed in milligrams per seedling.

The experiment was set up in a complete randomized block design with a $3 \times 2 \times 1+1$ factorial arrangement (three osmotic potentials $x$ two priming periods $x$ two drying periods) and a control (seeds without priming or drying) with four replications. The germination and first counting results were transformed using the arc sen $(\mathrm{x} / 100)^{1 / 2}$ function. The data obtained were submitted to analysis of variance by the $F$ test using the ASSISTAT statistical software. The means were compared in simple arrangement by the Dunnett test $(\mathrm{p}<0.05)$ in order compare the treatments with the control.

\section{RESULTS AND DISCUSSION}

Priming of eggplant seeds with and without later drying did not result, for germination, in results superior to those from the control, for either of the lots. However, superior responses were obtained in the vigor parameters (Table 1). Kikuti et al. (2005) also reported that sweet pepper seeds primed with PEG 6000 performed better in all the vigor tests assessed, except the germination test.

The best vigor results were obtained for the seeds in lot 1, especially in the osmotic treatments with later drying, except for the GSI, where both presence and absence of post-priming and drying resulted in superior values to those of the control. Even without drying, improvements for vigor were obtained in the seeds of this lot, except for the results of the first count and seedling dry matter.
Regarding the seeds in lot 2 , improvements were also observed for vigor, both with and without drying, but they were not greater than those obtained in lot 1 , represented by the majority of the tests. Emergence is highlighted within the vigor parameters analyzed in this lower quality lot because superior values were observed to those of the control in all the osmotic potentials and priming periods studied, with and without post drying treatment, that is, there was increased vigor in the primed seeds.

Thus it was observed that osmotic priming resulted in improvements in the lot vigor under both laboratory and field conditions, represented in the latter by GSI and emergence. Differently, Dias et al. (1999) did not observe benefits from PEG 6000 in okra seedling emergence. Fanan \& Novembre (2007), in seeds of three eggplant lots, also did not observe effect of priming and drying on seedling emergence.

Nunes et al. (2000) worked with priming of onion seeds allied or not to chemical treatment and reported that lower initial lot quality may have direct consequences on seedling establishment, affecting not only germination but also the emergence speed. Thus it can be inferred, from the point of view of the initial quality of the eggplant lots that the improvements obtained in lot 2 were more important and necessary compared to those obtained in lot 1 that had extremely low physiological quality. As seen, although there were no differences in the germination potential, when the two lots were compared (regarding vigor) it can be observed in the lot with greater physiological damage (Lot II) that the tests, especially emergence, were able to detect significant improvements in this lot. Bittencourt et al. (2005) also observed that the beneficial effects of priming were more expressive for vigor in the low physiological quality lot and at germination. According to Heydecker et al. (1975) low quality seeds submitted to priming tend to improve in vigor, due to reorganization of the cell membrane structures, resulting in greater seedling uniformity and emergence.

Generally, both the lots responded well to priming, but this response depended on the osmotic potentials and priming periods studied, and the drying and vigor level of the lot. Fessel et al. (2001) reported that the response of lettuce seeds to osmotic priming with mannitol also depended on the vigor level and priming period. Roveri-José et al. (2000) reported that priming in tomato seeds was influenced by the primng time and temperature, and that the technique also improved the seed performance of intermediate quality sweet pepper (low germination percentage).

Based on the results presented in Table 1, statistically, inferior results were not observed but rather results superior or equal to those of the controls for both the lots. Thus, the osmotic treatments increased vigor in the eggplant seeds and in the last instance, maintained the original vigor. In the case of drying, the benefits of the priming were maintained for most of the osmotic treatments used.

\section{ACKNOWLEDGEMENTS}

The authors thank Prof Dr. Roberval Daiton Vieira and Dr. Magnólia de Mendonça Lopes (UNESP-FCAV) for supplying the eggplant seeds.

\section{REFERENCES}

ARGERICH RB; BRADFORD KJ; TARQUIS AM. 1989. The effects of priming on resistance to deterioration of tomato seeds. Journal of Experimental Botany 40: 593-598.

BALBINOT E; LOPES HM. 2006. Efeitos do condicionamento fisiológico e da secagem na germinação e no vigor de sementes de cenoura. Revista Brasileira de Sementes 28: 01-08.

BITTENCOURT MLC; DIAS DCFS; DIAS LAS; ARAÚJO EF. 2004a. Efeito do condicionamento osmótico das sementes na germinação e no crescimento das plântulas de aspargo. Revista Brasileira de Sementes 26: $50-56$.

BITTENCOURT MLC; DIAS DCFS; DIAS LAS; ARAÚJO EF. 2004b. Effects of priming on asparagus seed germination and vigour under water and temperature stress. Seed Science and Technology 32: 607-616.

BITTENCOURT MLC; DIAS DCFS; DIAS LAS; ARAÚJO EF. 2005. Germination and vigour of primed asparagus seeds. Scientia Agricola 62: 319-324.

BRASIL. 1992. Ministério da Agricultura e Reforma Agrária. Secretaria Nacional de Defesa Agrária. Departamento Nacional de Produção Vegetal. Coordenação de 
Laboratório Vegetal. Regras para análise de sementes. Brasília, DF. 365 p.

CASEIRO R; BENNETT MA; MARCOS FILHO J. 2004. Comparison of three priming techniques for onion seed differing in initial seed quality. Seed Science and Technology 32: 365-375.

DIAS DCFS; PAIXAO GP; SEDIYAMA MAN; CECON PR. 1999. Pré-condicionamento de sementes de quiabo: efeitos na qualidade fisiológica e no potencial de armazenamento. Revista Brasileira de Sementes 21: 224-231.

DIAS MA; AQUINO LAA; DIAS DCFS; ALVARENGA EM. 2009. Qualidade fisiológica de sementes de beterraba (Beta vulgaris L.) sob condicionamento osmótico e tratamentos fungicidas. Revista Brasileira de Sementes 31: 188-194.

FANAN S; NOVEMBRE ADLC. 2007. Condicionamento fisiológico de sementes de berinjela. Bragantia 66: 675-683.

FESSEL SA; VIEIRA RD; RODRIGUES TJD; FAGIOLI M; DE PAULA RC. 2001. Eficiência do condicionamento osmótico em sementes de alface. Revista Brasileira de Sementes 23: 128-133.

HEYDECKER W; HIGGINS J; TURNER IJ. 1975. Invigoration of seeds? Seed Science and Technology 3: 881-888.

KIKUTI ALP; KIKUTI H; MINAMI K. 2005. Condicionamento fisiológico em sementes de pimentão. Revista Ciência Agronômica 36: $243-248$

KIKUTI ALP. 2006. Avaliação do potencial fisiológico, métodos de condicionamento e desempenho de sementes de couve-flor (Brassica oleraceae L. var. botrytis) durante o armazenamento e em campo. Piracicaba: USP-ESALQ. 155 p (Tese doutorado).

LIMA LB; MARCOS FILHO J. 2009. Condicionamento fisiológico de sementes de pepino e relação com desempenho das plantas em campo. Revista Brasileira de Sementes 31: 27-37.

LOPES HM; SOUZA CM. 2008. Efeitos da giberelina e da secagem no condicionamento osmótico sobre a viabilidade e o vigor de sementes de mamão (Carica papaya). Revista Brasileira de Sementes 30: 181-189.

MAGUIRE JD. 1962. Speed of germinationaid in selection and evaluation for seeding emergence and vigor. Crop Science 2: 176-177.

MARCOS FILHO J; KIKUTI ALP. 2008. Condicionamento fisiológico de sementes de couve-flor e desempenho das plantas em campo. Horticultura Brasileira 26: 165-169.

NAKAGAWA J. 1999. Testes de vigor baseados no desempenho das plântulas. In: KRZYZANOSKI FC; VIEIRA RD; FRANÇA NETO JB. (eds). Vigor de sementes: conceitos e testes. Londrina: ABRATES. 218 p.

NASCIMENTO WM. 1998. Condicionamento osmótico de sementes de hortaliças: potencialidades e implicações. Horticultura Brasileira 16: 106-109.

NUNES UR; SANTOS MR; ALVARENGA EM; DIAS DCFS. 2000. Efeito do condicionamento osmótico e do tratamento com fungicida na qualidade fisiológica e sanitária de sementes de cebola (Allium cepa L.). Revista Brasileira de Sementes 22: 239-246.

ODETOLA AA; IRANLOYE YO; AKINLOYE O. 2004. Hypolipidaemic potentials of Solanum melongena and Solanum gilo on hypercholesterolemic rabbits. Pakistan Journal of Nutrition 3: 180-187.

PEREIRA CE; OLIVEIRA JA; GUIMARAES RM; VIEIRA AR; SILVA JBC. 2005. Condicionamento fisiológico e revestimento de sementes de pimentão. Revista Ciência Agronômica 36: 74 -81.

PEREIRA MD; DIAS DCFS; DIAS LAS; ARAUJO EF. 2009. Primed carrot seeds performance under water and temperature stress. Scientia Agricola 66: 174-179.

ROSSETTO CAV; LIMA TM; NAKAGAWA J. 2002. Qualidade fisiológica e potencial de armazenamento de sementes de tomate submetidas ao condicionamento osmótico. Horticultura Brasileira 20: 630-634.

ROVERI-JOSÉ SCB; VIEIRA MGGC; GUIMARAES RM. 2000. Efeito da temperatura e do período de condicionamento osmótico na germinação e no vigor de sementes de pimentão. Revista Brasileira de Sementes 22: 176-184.

VILLELA FA; DONI FILHO L; SEQUEIRA EL. 1991. Tabela de potencial osmótico em função da concentração de polietilenoglicol 6000 e da temperatura. Pesquisa Agropecuária Brasileira 26: 1957-1968. 